\title{
How a 'Global Pact for the Environment' could add value to international environmental law
}

\author{
Christina Voigt
}

\section{Correspondence}

Email: christina.voigt@jus.uio.no

The initiative for a 'Global Pact for the Environment' has over the course of the last year evolved into a global discourse. The United Nations (UN) General Assembly, the UN Secretary-General, UN Environment Programme, UN member States and a vast variety of nongovernmental organizations and academics are considering the need for and possible content of a Pact. It appears that to gather necessary political support, a Pact needs to add value to already existing international environmental law. This article offers input into the debate as to whether and how a Global Pact could achieve this. It argues that a Global Pact needs not be limited to a single treaty codifying environmental principles. Rather, it should be guided by what is needed to increase the effectiveness of environmental protection. In this sense, a Pact could address challenges in the implementation of multilateral environmental agreements (MEAs), help overcome coordination deficits between MEAs and between MEAs and other international treaties, or bring together actors from the public and private sector. It could provide a common vision for global environmental action and/or a framework for bringing the different pieces, i.e. sectoral and spatial agreements, together. Moreover, it could advance the development of international environmental law into areas that thus far have not been covered. The article gives a brief history of the initiative for the Global Pact, placing it against the nature and structure of international environmental law. It analyses the proposals made so far as to the possible scope, nature and content of a Pact, and provides suggestions for how it could contribute to the increased effectiveness, scope or scale of international environmental law.

\section{INTRODUCTION: A PACT FOR WHAT?}

The initiative for a Global Pact for the Environment was launched by French President Emmanuel Macron at the United Nations (UN) General Assembly in September 2017 during a special event. It is based on various previous attempts to establish a global 'pact for nature', informed by input from the French Club des Juristes together with a group of experts in international environmental law, and chaired by the president of the 2015 Paris climate conference and President of the Constitutional Council of the French Republic, Laurent Fabius. ${ }^{2}$

The proponents of the initiative suggest that the Global Pact for the Environment should be a global legally binding covenant for international environmental law and a major reference for global environmental governance. ${ }^{3}$ The objective is 'to codify, within a single document,

\footnotetext{
${ }^{1}$ Examples include the Earth Charter (see, e.g., M Lavrik, A Jimenez and M Vilela, 'The Global Pact for the Environment as a Next Step on the Way Forward for the Earth Charter' (Earth Charter International Secretariat 2018) <http://earthcharter.org/wp-content/uploads/2018/07/Global-Pact-and-Earth-Charter-2018.pdf >); the World Charter for Nature; and the Rio Declaration on Environment and Development.

2 'Draft Global Pact for the Environment' (24 June 2017) $<$ https://www.iucn.org/sites/dev/files/content/documents/draft-project-of-the-global-pact-for-theenvironment.pdf $>$. For further background, see Y Aguila and J Viñuales, 'A Global Pact for the Environment: Conceptual Foundations' (2019) 28 Review of European, Comparative and International Environmental Law.

${ }^{3}$ J Ferrero and Y Aguila, 'Introductory Report on the Draft Global Pact for the Environment' (on file with the author) 5. See also Le Club des Juristes, 'White Paper - Toward a Global Pact for the Environment' (September 2017) <https://www.leclubdesjuristes.com/wp-content/uploads/2017/05/CDJ_Pacte-mondial-pourlenvironnement_Livre-blanc_UK_web.pdf $>$.
} 
internationally-accepted principles ... which structure the international protection of the environment'. ${ }^{4}$ With the Global Pact for the Environment, they claim,

the international community would be equipped for the first time with a treaty of a general nature that covers all environmental areas. It would be the cornerstone of international environmental law and constitute an 'umbrella text' that thereby oversees the different existing sectoral agreements (e.g. climate, biodiversity, waste, pollution). The Pact is not intended to substitute for these sectoral treaties. Instead, it aims to complement them and facilitate their implementation. It would therefore fill any of their gaps or even would be applied in addition to them where there is no incompatibility, thus making them more effective and efficient. ${ }^{5}$

The legally binding manifestation of environmental principles is suggested to have a beneficial impact on the general structure of international environmental law by creating coherence and completeness in the sector-specific array of hundreds of multilateral environmental treaties. ${ }^{6}$ Moreover, the proponents claim that the Global Pact for the Environment could potentially, over time, also exert legal influence on the domestic legal setup of parties in two respects: on the legislature, by obliging State parties to implement the principles into national law; and on the judiciary, which may use the principles of the Pact by either applying them directly and thereby filling gaps in national laws and regulations, or by using them as interpretative means. ${ }^{7}$

It is worthwhile analysing the suggested purposes in more detail in order to assess the potentially added value of a Global Pact for the Environment to the existing body of international environmental law. This, however, requires us to first gain a better understanding of the nature of international environmental law.

\section{A PRIMER ON THE NATURE OF INTERNATIONAL ENVIRONMENTAL LAW}

International environmental law is the area of public international law which addresses States and international organizations with respect to the environment. ${ }^{8}$ It does not operate in isolation, but is anchored in the rules and principles of general public international law, such as State sovereignty, pacta sunt servanda and State responsibility. It consists of a vast body of treaty law - i.e. bilateral, regional and multilateral agreements - and a few customary norms and general principles. ${ }^{9}$ Regional and multilateral environmental agreements (MEAs) cover a range of specific environmental issues. ${ }^{10}$

\footnotetext{
${ }^{4}$ Ferrero and Aguila (n 3) 6.

${ }^{5}$ Permanent Mission of France to the United Nations, 'The UN Should Adopt the Global Pact for the Environment' (2018) < https://onu.delegfrance.org/The-UN-should-adopt-the-Global-Pact-for-the-Environment>.

${ }^{6}$ Aguila and Viñuales (n 3).

${ }^{7}$ Symposium at the European Parliament, 6 February 2019, interventions by Laurent Fabius and Yann Aguila $<$ http://www.leclubdesjuristes.com/conference-au-parlement-europeen-autour-du-pacte-mondial-pourlenvironnement-le-6-fevrier-2019/>.

${ }^{8}$ See A Boyle and C Redgwell, International Law and the Environment, 4th edn (Oxford University Press 2019); D Bodansky, The Art and Craft of International Environmental Law (Harvard University Press 2011); and D Bodansky, J Brunnée and E Hey (eds), Oxford Handbook of International Environmental Law (Oxford University Press 2007).

${ }^{9}$ P Sands and J Peel (2018) Principles of International Environmental Law, 4th edn (Cambridge University Press 2018).

${ }^{10}$ United Nations Environment Programme (UNEP), Training Manual on International Environmental Law (UNEP 2006).
} 
The general structure of international law, international environmental law included, is fragmented. ${ }^{11}$ Identified (environmental and other) issues are being dealt with by sectoral, issuespecific, legally independent treaties, often spatially limited to specific regions. Fragmentation is the norm, not the exception, and as such an inherent characteristic of multilateral decisionmaking aiming to address the diversity of specific challenges. Neither is it negative or a threat per se; rather it is politically inevitable - reflective of the (legal and political) plurality of issues $^{12}$ - and legally manageable. ${ }^{13}$ Still, fragmentation and unsystematic development have been seen by some as creating the risk of inconsistent obligations, overlapping norms and outright duplication. ${ }^{14}$ Others noted, however, that the normative overlap has largely been without incident and is mostly benign. ${ }^{15}$

International environmental law does not have an overarching general normative framework. Some have suggested that the Rio Declaration could assert such a framework function. ${ }^{16}$ Others proposed the consideration of a new framework convention. ${ }^{17}$ It has been noted that other areas of international law have a binding framework instrument that brings together sectoral or regional instruments under the same normative umbrella and provides for a certain degree of coordination and coherence. Examples include human rights covenants, international trade law, or the international law of the sea. In most of these areas, however, the framework agreements codified existing customary norms and, in most if not all cases, predated the development of more specific treaties; they were not adopted ex post factum.

The fragmented structure of international law and the incremental or piecemeal process of regime creation has inevitably led to the situation where some environmental challenges are addressed, while others are not, depending on whether certain initiatives, scientific findings or environmental disasters mobilized States into negotiations.

Many modern MEAs have almost universal membership. Where the relevant environmental problems at stake are of a global nature, the solution lies in collective action. ${ }^{18}$ The challenge in this situation is to encourage participation of all relevant actors while, at the same time, ensuring that the duties are ambitious enough to effectively respond to the problem, and to ensure that parties comply with their duties. ${ }^{19}$ Broad participation and legal stringency

\footnotetext{
${ }^{11}$ See H van Asselt, 'Managing the Fragmentation of International Environmental Law: Forests at the Intersection of the Climate and Biodiversity Regimes' (2012) 44 New York University Journal of International Law and Politics, 1205.

12 PS Berman, 'Global Legal Pluralism' (2007) 80 Southern California Law Review1155; see also WW BurkeWhite, 'International Legal Pluralism' (2004) 25 Michigan Journal of International Law 963.

13 International Law Commission, 'Fragmentation of International Law: Difficulties Arising from the Diversification and Expansion of International Law' UN Doc A/CN.4/L.682 (13 April 2006), as corrected in UN Doc A/CN.4/L.682/Corr.1 (11 August 2006).

${ }^{14}$ EB Weiss, 'International Environmental Law: Contemporary Issues and the Emergence of a New World Order' (1993) 81 Georgetown Law Journal 675, 697-702. See also Bodansky (n 8) 35 (describing 'treaty congestion' as a similar result of the proliferation of MEAs, which 'creates the potential for duplication in effort, lack of coordination, and even conflict between different environmental regimes'); and R Wolfrum and N Matz, Conflicts in International Environmental Law (Springer 2003).

${ }^{15}$ T Stephens, International Courts and Environmental Protection (Cambridge University Press 2009).

${ }^{16}$ See for a discussion of this absence and the potential of the Rio Declaration to function as an 'unlikely constitution': JE Viñuales, 'The Rio Declaration on Environment and Development: Preliminary Study' in JE Viñuales (ed), The Rio Declaration on Environment and Development: A Commentary (Oxford University Press 2015) 1 .

${ }^{17}$ UNEP, 'Future Shape of International Law to Address Pollution of Global Significance Affecting the Earth's Ecosystems (6 April 2018) $<$ https://wedocs.unep.org/bitstream/handle/20.500.11822/26339/Future_International_Law.pdf?sequence=1\&isA llowed $=\mathrm{y}>$.

18 See E Ostrom, Governing the Commons: The Evolution of Institutions for Collective Action (Cambridge University Press 1990); see also E Ostrom, 'Polycentric Systems for Coping with Collective Action and Global Environmental Change’ (2010) 20 Global Environmental Change 550.

${ }^{19}$ See S Barrett, Environment and Statecraft: The Strategy of Environmental Treaty-Making (Oxford University
} 
are often at cross-purposes. To gain global acceptance for a legal instrument, a wide variety of interests needs to be considered and balanced against each other. The involvement of a large number of States with diverse national circumstances and priorities leads to the fact that MEAs often serve multiple objectives and have to be considered in the context of sustainable development. For example, the Convention on Biological Diversity (CBD) pursues the broad objectives of conservation of biological diversity, the sustainable use of its components, and the fair and equitable sharing of the benefits arising out of the utilization of genetic resources. ${ }^{20}$ The different objectives are not always easily reconciled and mutually enhanced, but they arise out of political compromises struck between different interests. ${ }^{21}$ Without these compromises and (often intended) constructive ambiguities and gaps, however, the likelihood of States agreeing to international environmental accords would be significantly diminished, which in turn would undermine the success of creating global playing fields and cooperation on urgent, global environmental issues.

Broad participation also relies on workable notions of fairness, including equitable burden- and effort-sharing. MEAs therefore often contain provisions that take into account differing circumstances. ${ }^{22}$ These can be States' historical or current responsibilities in causing an environmental problem, their capacities to remedy the problem or other factors, such as technical capabilities, human capacity, population size and other demographic criteria, abatement costs, opportunity costs, and skills. Differentiation, a prominent feature of international environmental law but also part of other areas of international law, represents a formal departure from the strict and equal treatment of States. By taking differences into account, certain groups of States, often developing countries, are subject to 'softer' obligations, for example longer phase-out periods or more flexible targets. ${ }^{23}$ The idea is to bring about practical, rather than formal, equality among de facto unequal States, and to increase participation in, and the effectiveness of, international agreements. Differentiation leads to situations where (not all) provisions/obligations have the same legal stringency for all parties. However, this situation is a necessary requirement to bring all relevant actors on board. Indeed, in a world characterized by more diffuse international power structures, identifying ways and means of cooperation in addressing global challenges will require more, rather than less, differential treatment, exceptionalism, and flexibility. ${ }^{24}$

Last but not least, the principles of State sovereignty and of permanent sovereignty over natural resources resonate strongly in the negotiations (and content) of international environmental treaties. As each treaty is, in effect, a compromise which guides, directs and, in many cases, limits certain sovereign rights, States as the law-making powers are often reluctant to accept overly intrusive obligations. ${ }^{25}$ As a consequence, international environmental treaties often take a 'framework/protocol' approach. In a first step, a framework treaty (often called 'convention, ${ }^{26}$ ) is adopted, containing general guidelines, overall purpose(s) or objective(s),

\footnotetext{
Press 2003); OR Young, International Cooperation: Building Regimes for Natural Resources and the Environment (Cornell University Press 1989); and OR Young, The Institutional Dimension of Environmental Change: Fit, Interplay and Scale (MIT Press 2002).

${ }^{20}$ Convention on Biological Diversity (adopted 5 June 1992, entered into force 29 December 1993) 1760 UNTS 79 (CBD) art 1.

${ }^{21} \mathrm{~S}$ Humphreys and Y Otomo, 'Theorizing International Environmental Law' in F Hoffmann and A Oxford (eds), The Oxford Handbook of International Legal Theory (Oxford University Press 2014) 797.

${ }^{22}$ See L Rajamani, Differential Treatment in International Environmental Law (Oxford University Press 2006).

${ }^{23}$ ibid.

${ }^{24}$ O Stuenkel, Post Western World (Polity 2016).

${ }^{25}$ See NJ Schrijver, Sovereignty over Natural Resources, Balancing Rights and Duties (Oxford University Press 2009).

${ }^{26}$ For instance, CBD (n 20); United Nations Framework Convention on Climate Change (adopted 9 May 1992, entered into force 21 March 1994) 1771 UNTS 107 (UNFCCC); United Nations Convention on the Law of the Sea (adopted 10 December 1982, entered into force 16 November 1994) 1833 UNTS 3.
} 
and principles. The idea is to garner initial, widespread support among States to address a certain environmental issue. The expectation is that, over time and with more experiences and expertise as well as increasing scientific certainty and technological advances, more specific and effective norms can be agreed to, often contained in subsequent protocols or implementing agreements. This way, incremental progress can be achieved, based on mutual learning and trust. The basic idea of this approach is to first 'broaden' participation and then 'deepen' parties' commitments over time. ${ }^{27}$ The initial stage(s) are therefore necessarily characterized by high generality and ambiguity as well as gaps, and the understanding that norm development over time is necessary.

As a consequence, international environmental law often appears fragmented and uncoordinated, something which lies in the very nature of complex environmental challenges. Dynamic norm development might be able to remedy some of the challenges, over time. It is against this backdrop that the initiative for a Global Pact for the Environment needs to be considered.

\section{GAPS IN INTERNATIONAL ENVIRONMENTAL LAW}

It is not surprising that the initiative for a Global Pact for the Environment has met with mixed responses. During the discussions at the UN level, ${ }^{28}$ as well as in the academic literature, it has garnered support as well as scepticism and criticism. ${ }^{29}$ The main concern expressed by many States is that an initiative like this would need to add value to the existing international legal system for the protection of the environment. The structure of international environmental law, as just described, certainly leaves room for improvement. The question, however, is whether a Global Pact for the Environment would be the right tool to making the necessary changes.

To gain more clarity on whether there is indeed a need for such pact, States agreed to assess whether there are gaps or deficiencies in international environmental law. The initiative has so far resulted in a resolution by the UN General Assembly, ${ }^{30}$ which requested the UN Secretary-General (UNSG) to issue a 'technical and expert-based report that identifies and assesses possible gaps in international environmental law and environment-related instruments with a view to strengthening their implementation', ${ }^{31}$ and established 'an ad-hoc open-ended working group (OEWG) to consider the report and discuss possible options to address possible gaps in international environmental law and environment-related instruments, as appropriate, and if deemed necessary, the scope, parameters and feasibility of an international instrument,

\footnotetext{
${ }^{27}$ Bodansky (n 8).

28 See UNEP, 'Towards a Global Pact for the Environment' $<$ https://www.unenvironment.org/events/conference/towards-global-pact-environment>; and AM Lebada, 'UNGA Adopts Resolution on Global Environment Pact' (SDG Knowledge Hub, 24 May 2018) $<$ https://sdg.iisd.org/news/unga-adopts-resolution-on-global-environment-pact/>. See also P Doran, L BullonCassis and N Jones, 'Summary of the First Substantive Session of the Ad Hoc Open Ended Working Group towards a Global Pact for the Environment, 14-18 January 2019' (2019) 354 Earth Negotiations Bulletin 1.

${ }^{29}$ In support, see M Kenig-Witkowska, 'The Draft Global Pact for the Environment' (ClientEarth Prawnicy dla Ziemi Foundation 2018); Aguila and Viñuales (n 3); and MA Young, 'Global Pact for the Environment Defragging International Law?' (EJIL:Talk!, 29 August 2018). For a more critical approach, see LJ Kotzé and D French, 'A Critique of the Global Pact for the Environment: A Stillborn Initiative or the Foundation for Lex Anthropocenae?' (2018) 18 International Environmental Agreements: Politics, Law and Economics 811; D French and LJ Kotze, "“Towards a Global Pact for the Environment”: International Environmental Law's Factual, Technical and (Unmentionable) Normative Gaps' (2019) 28 Review of European, Comparative and International Environmental Law; and S Biniaz, 'The UNGA Resolution on a "Global Pact for the Environment": A Chance to Put the Horse before the Cart' (2019) 28 Review of European, Comparative and International Environmental Law. ${ }^{30}$ UNGA 'Towards a Global Pact for the Environment' UN Doc A/RES/72/277 (10 May 2018) (Resolution 72/277).

31 ibid para 1.
} 
with a view to making recommendations', ${ }^{32}$ while recognizing that this process 'should not undermine existing relevant legal instruments and frameworks and relevant global, regional and sectoral bodies'. 33

The UNGA resolution, the UNSG report as well as the discussions during the first session of the OEWG need to be seen as preliminary steps to assess whether there is a need for a Global Pact for the Environment. The report by the UNSG was released on 18 December $2018^{34}$ and, at the time of writing, has been subject of the discussions during first substantive session of the OEWG, held in Nairobi from 14-18 January 2019.

\subsection{The UNSG report}

The UNSG report adopts a wide interpretation of its mandate 'to identify and assess possible gaps in international environmental law and environment-related instruments with a view to strengthening their implementation'. 35

First, it adopts a broad interpretation of what constitutes a 'gap'. A gap is defined as a lacuna, void, defect or deficiency; borrowing this definition from a legal dictionary. While there certainly could have been more methodological stringency in defining what a gap is, ${ }^{36}$ the broad interpretation focusing on effectiveness of international environmental law, however, allows for exploring a wider set of parameters than merely the absence of rules and law. Effectiveness challenges to international environmental law might reside in 'too much' rather than 'too little' law, or in the dissonant relationship between different treaties or in the insufficient implementation of and compliance with existing law.

Second, it not only identifies and assesses regulatory (i.e. procedural and substantive) and governance gaps in international environmental law, but also assesses gaps in environmentrelated instruments. These instruments are understood not as 'soft' (i.e. non-legally binding) environmental instruments, as some might have expected, but as other international legal instruments that do not have environmental protection as their main object and purpose, but directly or indirectly interact and interlink with environmental issues. Environment-related instruments therefore include areas such as international trade, investment, intellectual property, human rights, peace and security, migration, disaster management and armed conflict. While this interpretation may have come as a surprise to those that expected a narrow scope of the report, it helps to shed light on some of the major reasons for the limited effectiveness of international environmental law. These reasons may not (exclusively) lie within the body of international environmental treaties, but (also) at the interface of, legal relationship with, and constraints imposed by, other areas of international law.

Third, a narrow interpretation of paragraph 1 of the UNGA resolution might suggest that the question of how to address any potentially identified gaps would be subject to the OEWG deliberations, and would therefore not be part of the mandate for the report. Nonetheless, the report makes several significant suggestions and recommendations. Most prominent among them is the recommendation that international environmental law and its effective implementation could be strengthened through such actions as the clarification and reinforcement of principle of international law. This could be done through a comprehensive

\footnotetext{
32 ibid para 2.

33 ibid para 9.

${ }^{34}$ UN Secretary-General, 'Gaps in International Environmental Law and Environment-Related Instruments: Towards a Global Pact for the Environment' UN Doc A/73/419 (30 November 2018) (UNSG Report).

${ }^{35}$ Resolution $72 / 277$ (n 30).

${ }^{36}$ See, e.g., S Biniaz, "10 Questions to Ask about the Proposed "Global Pact for the Environment" (Sabin Centre for Climate Change Law 2017) <http://columbiaclimatelaw.com/files/2017/08/Biniaz-2017-08-Global-Pact-forthe-Environment.pdf $>$.
} 
and unifying international instrument that gathers all the principles of environmental law. ${ }^{37}$ Recommendations like this led some States to suggest that the UNSG report did not comply with its mandate. ${ }^{38}$

The report identifies a wide range of gaps. According to its broadly interpreted mandate, it assesses gaps and deficiencies which impact on the effectiveness of international environmental law. These deficiencies include: (i) 'white spots' in the coverage of multilateral environmental agreements, (ii) the status and content of environmental principles, (iii) gaps within and (iv) between MEAs, (v) between MEAs and other international law, and with regard to (vi) implementation of MEAs. These will be discussed in turn below.

\subsection{1 'Blank spots'}

'Gaps' in their most obvious meaning, i.e. lacunae or unregulated environmental issues, are covered to a disappointingly limited extent. While one could have expected the report to shed light on environmental concerns that as of today lack coverage by MEAs, the report deals with those 'blank spots' only in a passing manner. It identifies the following issues as remaining without specific, legally binding regulation by international treaties: the conservation and sustainable use of forests, pollution of marine areas by land-based plastic debris, protection of biological diversity beyond national jurisdiction, the protection of soils, regulation of the use of pesticides, regulation of noise pollution, protection of the Arctic environment, a human right to biological diversity, regulation of nanomaterials and of geo-engineering processes. ${ }^{39}$

The report is silent about whether and how a Global Pact should address those 'blank spots'. Despite the brevity of dealing with those unaddressed issues, it stands to hope that the fact that they are mentioned helps garnering attention and action around them.

\subsubsection{Principles}

The question of the scope, content and legal status of environmental principles is addressed over seven pages. While a significant effort was made to assess environmental principles, more detail would have been warranted.

The selection of principles is mainly based on the 1992 Rio Declaration, although the report also takes note of more recent developments. The report covers the following principles: prevention (in the context of sovereignty over natural resources and the prohibition of transboundary harm), precaution, polluter pays, environmental democracy, cooperation, right to a clean and healthy environment, sustainable development, common but differentiated responsibilities and respective capabilities, and the corollary principles of non-regression and progression.

It concludes that most of these principles have been incorporated in sector-specific MEAs, with the exception of the right to a clean and healthy environment. Some principles even have gained the status of customary law and have been referred to by international courts and tribunals. ${ }^{40}$ Some principles, such as polluter pays ${ }^{41}$ and cooperation ${ }^{42}$ have a more specific content, while most of the other principles lack clarity regarding their legal nature and/or content (to varying extents) and applicability, and are not fully developed, such as the right to

\footnotetext{
${ }^{37}$ UNSG Report (n 34) 2.

${ }^{38}$ Doran et al (n 28). See also statements by UN members at the first substantive session of the OEWG: $<$ https://www.unenvironment.org/events/conference/towards-global-pact-environment $>$.

${ }^{39}$ See UNSG Report (n 34) paras 42 and 104; while recognizing that some of theses issues are partly covered by MEAs or currently under negotiation.

${ }^{40}$ See C Voigt (ed), International Judicial Practice on the Environment (Cambridge University Press 2019).

${ }^{41}$ See P Schwartz, 'Principle 16: The Polluter-Pays Principle' in Viñuales (n 16) 429, 435.

${ }^{42}$ PH Sand, 'Principle 27: Cooperation in a Spirit of Global Partnership' in Viñuales (n 16) 617.
} 
a clean and healthy environment and non-regression. The report notes further that there are instances where there is no clarity as to the nature and content of a principle, or no judicial consensus as to its applicability, or no recognition in binding legal instruments, or all of the above. The degree of legal uncertainty surrounding many of these principles has a direct and indirect impact on the predictability and implementation of sectoral regimes. ${ }^{43}$

The report also notes that differing expressions and understandings of principles exist in many issue-specific MEAs. ${ }^{44}$ Importantly, the report points out that when enshrined in legally binding MEAs, the scope and content of the relevant principles are confined to that particular MEA. It also addresses the dynamic function of principles in terms of filling gaps in the treaties in which they are contained. The general character of principles is recognized as an important element in the dynamic, continuously evolving development of international environmental law. They inform the way in which MEAs can be interpreted, and may fill the gaps in the rules laid out in those treaties. ${ }^{45}$

The report recognizes that more clarification of the content and scope of the principles would make them more effective, predictable and strengthen their implementation. It does go as far as suggesting a 'comprehensive and unifying international instrument' in this regard, ${ }^{46}$ giving rise to the criticism of exceeding its mandate as expressed above. At the same time, it cautions that codification could undermine the dynamic aspect of principles, such as sustainable development and common but differentiated responsibilities and respective capabilities. ${ }^{47}$ Importantly, however, the report clearly warns that any clarification of principles has to avoid digression, regression and back-tracking ('without prejudice') from the legal developments already achieved in the issue-specific context of various MEAs. ${ }^{48}$ This is an important statement, and corresponds to the requirement expressed in the UNGA resolution that the process 'towards a global pact for the environment should not undermine existing relevant legal instruments and frameworks and relevant global, regional and sectoral bodies'. ${ }^{49}$

\subsubsection{Gaps within existing MEAs}

Due to spatial and time limitations, the report only covers certain aspects of the landscape of international environmental law, such as the protection of the atmosphere (including climate change, protection of the stratospheric ozone layer, mercury and transboundary air pollution), conservation of biological diversity and the protection of soils, the protection of freshwater resources and of oceans and seas, as well as the regulation of hazardous wastes and activities.

In this context, the report notes that many of the gaps within MEAs are gaps by design. They came about by intention or arose out of the need for constructive ambiguity to reconcile diverse interests. There are very few gaps in the substance of MEAs that are unintended. Most of the gaps which the report identifies rather relate to implementation, such as ineffectiveness in monitoring, reporting and verification, compliance and enforcement, the absence of liability rules, or to the need for better harmonization, synergies and coordination with other MEAs.

The report makes few recommendations on how those gaps should be addressed, but seems to suggest that gaps within MEAs should be addressed by the specific means available within each respective MEA, such as amendments, protocols, implementing agreements, subsequent practice or evolving interpretation by its parties.

\footnotetext{
${ }^{43}$ UNSG Report (n 34) para 102.

44 ibid 2.

45 ibid para 101.

${ }^{46}$ ibid para 10.

${ }^{47}$ ibid para 20.

48 ibid para 102.

${ }^{49}$ Resolution $72 / 277$ (n 30) para 9.
} 


\subsubsection{Gaps between MEAs (governance gaps)}

The UNSG report highlights the fragmented structure of international environmental law, which is as explained above, a general phenomenon of international law and a consequence of multilateral decision-making. International environmental law consists of hundreds of sectorspecific MEAs which operate within their own mandates and institutional structures. Each agreement seeks to address a specific environmental issue and is institutionally and legally distinct from others. While this situation does not seem to cause outright 'conflicts' between MEAs, it leads to a certain extent to a lack of coordination and synergies between MEAs. The problem here is not so much a 'gap', but rather a risk of parallel efforts and the potential of duplication and inefficiencies.

The report mentions a few examples, but indicates that the problem might be of a larger scale than what is covered in the report. An example of parallel efforts concerns the environmentally safe handling and disposal of mercury wastes under the Minamata Convention on Mercury and the Basel Convention on the Control of Transboundary Movements of Hazardous Wastes and Their Disposal. ${ }^{50}$ The report suggests measures to harness linkages and synergies between related MEAs and proposes more frequent use of cross-references and priority clauses or conflict clauses in agreements, decisions on coordination and cooperation or the more frequent use of clustering of related agreements. ${ }^{51}$ Importantly, the report points to the principle of mutual supportiveness as a possible means to strengthen synergies between MEAs. ${ }^{52}$

On the institutional level, the report notes the proliferation and fragmentation of institutions and weak coordination among them. It provides a whole catalogue of means to address this situation, such as (i) creating clusters and synergies between environmental conventions; (ii) mapping the content of existing MEAs and action plans in order to create an overview of their respective scope and coverage and in order to identify linkages and overlaps; (iii) avoiding duplication of reporting and/or monitoring processes by using the same channels for different MEAs; (iv) sharing lessons learned and best practices; (v) developing implementation guidelines for MEAs; and (vi) sharing information among the different scientific bodies that support the work of MEAs. ${ }^{53}$ Finally, it also suggests strengthening of the role of the UN Environment Programme (UNEP) as the leading global environmental authority.

\subsubsection{Gaps between MEAs and other international law}

Because of the broad interpretation of 'environment-related instruments', the UNSG report was able to analyse gaps in other areas of international law and at the interface of environmental and 'non-environmental' international law. The report notes that there is an 'important coordination deficit ... between multilateral environmental agreements and other environmentrelated instruments. Strengthening coordination and coherence could enhance the effectiveness of international environmental law. ${ }^{54}$

Specific examples relate to dealing with alien species under the CBD, International Civil Aviation Organization, the International Maritime Organization, the World Trade Organization

\footnotetext{
${ }^{50}$ UNSG Report (n 34) para 34.

${ }^{51}$ ibid paras 80 and 83 . See also WB Chambers, Interlinkages and the Effectiveness of Multilateral Environmental Agreements (UNU Press 2008).

${ }^{52}$ UNSG Report (n 34) para 83.

53 ibid.

54 ibid para 103.
} 
and the World Customs Organization; ${ }^{55}$ or the disclosure requirements for access to genetic resources under the CBD's Nagoya Protocol and the Patent Cooperation Treaty of the World Intellectual Property Organization. ${ }^{56}$

With respect to the relationship to the world trade regime, the report notes a 'widening gap', ${ }^{57}$ without going into detail (except for issues pertaining to intellectual property rights and access and benefit sharing with regard to genetic resources ${ }^{58}$ ), while in relation to investment agreements the report makes the general observation that 'normative gaps arise because the specific environmental concerns explicitly addressed in these [investment] agreements are limited, and have generally not evolved to include more recent concerns such as climate change and biodiversity'. ${ }^{59}$ The legally undefined relationship between international environmental law and other international treaties can lead to a situation of 'regulatory chill', with States in the context of MEAs taking a restrictive approach to the use of trade measures in addressing environmental challenge, for instance through import restrictions in supply-chains or border adjustment measures.

In a similarly general fashion, the report deals with the intersection between human rights treaties (and treaty bodies) and international environmental agreements. ${ }^{60}$ It does not detail whether greater coherence should be achieved between the two bodies of international law and, if so, how.

Given the opening to investigate the relationship with other areas of international law, the report appears to have missed an important opportunity. The brevity and generality of this part of the report does not do justice to the complex and important relationship between international environmental law and trade liberalization and other international objectives. This is even more so a gap (in the report) as this relationship might be an important factor for the general lack of effectiveness of global environmental protection. For example, unilateral trade measures, such as border adjustment measures, that attempt to establish a level playing field, might run afoul of WTO rules that prohibit trade-restrictive measures. ${ }^{61}$ Similarly, possible synergies which could increase mutual supportiveness between human rights treaties and environmental treaties are not in place because of path dependencies of developments within the respective fields. A thorough assessment of these gaps and deficiencies in the UNSG's report could have shed light on these important interactions and guided more attention to addressing them.

\subsubsection{Implementation gaps}

One of the most concrete and important gaps which the report identifies is the effective implementation of many MEAs. ${ }^{62}$ The report mentions several reasons for implementation deficits, such as: lack of adequate means of implementation (i.e. financial, technological and capacity-building means); lack of facilitation where there is a need for it; lack of coordination between relevant departments within and across sectors; insufficient monitoring and

\footnotetext{
${ }^{55}$ ibid para 43.

${ }^{56}$ ibid para 44.

57 ibid para 71 .

58 ibid para 73 .

59 ibid para 72 .

${ }^{60}$ ibid paras 74-76.

${ }^{61}$ See, e.g., H van Asselt, 'Legal and Political Approaches in Interplay Management: Dealing with the Fragmentation of Global Climate Governance' in S Oberthür and OS Stokke (eds), Managing Institutional Complexity: Regime Interplay and Global Environmental Change (MIT Press 2011) 59; C Voigt, Sustainable Development as a Principle of International Law: Resolving Conflicts between Climate Measures and WTO Law (Brill 2008).

${ }^{62}$ UNSG Report (n 34) para 85.
} 
enforcement; lack of political will and political support; and the inadequate involvement of nonState actors. These means primarily need to be addressed at the national level. With the exception of (i) the (somewhat unlikely) development of stronger compliance and liability mechanisms and rules, and (ii) better and clearer conditions for access to adequate means of implementation (and the provision thereof), international law may only to a limited extent enhance the effectiveness of implementation, which by definition is an issue of domestic and sovereign power.

In sum, the report identifies several deficiencies and inconsistencies, as well as areas that lack any type of legal regulation. Addressing them might require several approaches at several levels. The report suggests some of them. What it does not suggest, however, is a 'onesize-fits-all' instrument.

\subsection{First substantive session of the OEWG: Taking the temperature}

The first substantive session took place at the UNEP office in Nairobi in January 2019. At that meeting, delegates discussed the UNSG report, which had been released only a few weeks before the meeting. The report received a critical reception with wide gaps between delegates' views. It was noted that these views could be categorized in mainly three camps: 'Those who think that there are no gaps; those who agree with gaps as identified in the UNSG's report, but who don't agree with how they are formulated; and those who say there are gaps, but not the ones in the UNSG's report.' ${ }^{, 63}$

Differences in opinion became clear across the entire spectre of topics covered in the report. While some delegates were concerned about fragmentation of international environmental law, others saw this as an asset and a reflection of the diversity and growth of international environmental law. Among those that expressed concern about fragmentation, views differed on whether codifying principles would contribute to greater coherence and effectiveness. While some countries stressed the role of principles in this regard, others noted that work on principles could deviate attention from other important work - in particular from effective implementation - and could lead to duplication and overlaps of processes and, in the worst case, a re-opening of, and backtracking from, existing legally binding instruments. The discussions are set to continue during the second and the third substantive session of the OEWG and will end with a decision on whether to make a recommendation (and, if so, which) to the UNGA in the first half of 2019.

\section{HOW TO ADD VALUE TO INTERNATIONAL ENVIRONMENTAL LAW?}

The main issue which arose out of the report and the discussions of the OEWG is that a Global Pact for the Environment (or whatever the outcome might be) will only be meaningful and able to gather the necessary political support if it adds value to what already exists. In doing so, it will inevitably need to addresses some, though perhaps not all, of the challenges identified in the report.

A Global Pact for the Environment can be many things. It can be a legally binding document, a soft law declaration, a UN General Assembly resolution, a UNEA resolution, a guide, compact, vision, compass or a general framework, consisting of one or several documents. A debate on whether and how a Pact could contribute to strengthening environmental protection is as necessary as it is legitimate and important. But the discussions should go forward without prejudging the outcome. Clarity on the role and function of a Pact will have to be established before its (legal) form can meaningfully be discussed.

\footnotetext{
${ }^{63}$ Doran et al (n 28).
} 


\subsection{The role of principles in strengthening environmental protection}

Principles can and should play an important role in the further development of international environmental law. Principles provide a dynamic element of international law. ${ }^{64}$ Importantly, they are referred to in international jurisprudence and relied upon in the course of treaty interpretation. Principles are an important supplement and corrective to treaty law. ${ }^{65}$ Against this background, principles 'constitute both the backbone of the body of law governing international dealings and the potent cement that binds together the various and often disparate cogs and wheels of the normative framework of the international community' ${ }^{66}$ International law is a process; principles can evolve into conventional or customary rules, but principles will always (have to) remain 'unfinished'.

There are several reasons for this. Principles have emerged in the context of sharp differences as regards their meaning. Different States attach different understandings to the same principle. This situation is unlikely to change in an attempt to codify principles. Also, State practice in applying and interpreting principles is still evolving and will be determined, in part, by what States do on a national level and through international judicial practice by international courts and tribunals.

An update and consolidation of environmental principles might increase their visibility, relevance and their usage in international and national jurisprudence. They can facilitate interpretation and fill normative gaps in the absence of applicable rules. However, it is uncertain whether environmental principles per se would contribute to the strengthening of environmental protection, implementation or coordination and synergies between MEAs.

Potential conflicts between MEAs - if they arise at all - can be managed by using existing legal means. For instance, some international environmental treaties contain so-called conflict clauses, which aim at addressing potential overlaps with other international agreements (e.g. Article 22(1) CBD). ${ }^{67}$ Another means is the principle of mutual supportiveness, ${ }^{68}$ which requires parties when developing and implementing other relevant instruments to be supportive of, and not act counter to the objective of the instrument(s) in which the 'supportiveness' clause is contained (e.g. Article 4(2) Nagoya Protocol). ${ }^{69}$ Lastly, coordination and consistency between different legal instruments can also be achieved by interpreting and applying international environmental treaties in a harmonized manner. Yet, international law has very few interpretative principles which would support such coordination and harmonization. Different from domestic laws where sectoral laws need to be interpreted to be in accordance with constitutional law of a higher normative order, no such hierarchy exists in general public international law, nor within international environmental law. Principles which usually deal with potentially conflicting application of laws include the maxims of lex posterior derogat legi

\footnotetext{
${ }^{64}$ See M Bos, 'The Recognized Manifestations of International Law' (1977) 20 German Yearbook of International Law 42.

${ }^{65}$ R Higgins, Problems and Process: International Law and How We Use It (Clarendon Press 2003) 10.

${ }^{66}$ A Cassese, International Law (2nd edn, Oxford University Press 2004) 188.

67 'The provisions of this Convention shall not affect the rights and obligations of any contracting party deriving from any exiting international ageeement, except where the execrcise of those rights and obligations would cause a serious damage of threat to biological diversity.' CBD (n 20) art 22(1).

${ }^{68}$ R Pavoni, 'Mutual Supportiveness as a Principle of Interpretation and Law-Making: A Watershed for the "WTOand-Competing-Regimes” Debate?’ (2010) 21 European Journal of International Law 649.

69 'Nothing in this Protocol shall prevent the Parties from developing and implementing other relevant international agreements, including other specialized access and benefit-sharing agreements, provided that they are supportive of and do not run counter to the objectives of the Convention and this Protocol.' Nagoya Protocol on Access to Genetic Resources and the Fair and Equitable Sharing of Benefits Arising from their Utilization (adopted 29 October 2010, entered into force 12 October 2014) <https:/www.cbd.int/abs/doc/protocol/nagoya-protocolen.pdf>.
} 
priori or lex specialis derogat legi generali. However, in constantly evolving treaty regimes, which deal with different issues and different State memberships, these principles are of limited relevance and help.

One potentially important interpretative principle that could achieve some level of coordination and harmony between different norms in international environmental law is the principle of 'systemic integration' included in Article 31(3)(c) of the Vienna Convention on the Law of Treaties. ${ }^{70}$ According to this principle, when interpreting a treaty, 'there shall be taken into account, together with the context, ... any relevant rules of international law applicable between the Parties'. ${ }^{71}$ Despite its potential for creating more coherence, however, international courts have been reluctant in using this principle and hold different views on its applicability. ${ }^{72}$

To be effective and relevant, international legal instruments also need to be dynamic and respond to the ever-changing scientific knowledge base. Some international environmental treaties contain principled provisions for the application of best available scientific knowledge. ${ }^{73}$ As such, these treaties might evolve progressively as part of their structure and procedural set-up and principles can play an important role in this evolution. Other treaties need to be interpreted in a dynamic and evolutionary manner, taking into account new developments since their adoption. ${ }^{74}$

In any case, any work on environmental principles must be done with great care and skill. There are, at least, four apparent risks attached to the attempt to consolidate and codify or further develop principles.

First, there is the danger of retreating from, and undermining, existing expressions of principles in the context-specific setting of sectoral or regional MEAs. Principles have evolved in the almost three decades that have passed since the Rio Declaration. They have been adopted, adjusted and fine-tuned to fit the specific nature of the environmental challenge and the environmental regime at hand. In many cases, the evolution and specification of principles have been accompanied by controversial political debates and sensitive compromises.

One example is the development of the principle of 'common but differentiated responsibilities'. This principle has developed from the application of equity in general international law and the recognition that the special needs of developing countries should to be taken into account in the development and application of international environmental law. ${ }^{75}$ In practical terms, differentiation may result in different legal obligations. Its expression in the Rio Declaration ${ }^{76}$ as 'common but differentiated responsibilities' developed in the context of climate change to 'common but differentiated responsibilities and respective capabilities' in the UNFCCC, ${ }^{77}$ to its latest reflection in the Paris Agreement, which adds the phrase 'in the light of different national circumstances'. ${ }^{78}$ This addition was necessary to break a deadlock in the negotiations and to open the principle to a wider application of circumstances than only responsibility based on historical greenhouse gas emissions. ${ }^{79}$ In the course of this evolution,

\footnotetext{
${ }^{70}$ Vienna Convention on the Law of Treaties (adopted 23 May 1969, entered into force 27 January 1980) 25 ILM 679.

${ }^{71}$ ibid art 31(3)(c). See C McLachlan, 'The Principle of Systemic Integration and Article 31.3(c) of the Vienna Convention’ (2005) 54 International and Comparative Law Quarterly 279.

72 ibid.

${ }^{73}$ See, for example, the requirement in the Paris Agreement that the global stocktake needs to be informed by best availabe science. Paris Agreement (adopted 12 December 2015, entered into force 4 November 2016) 55 ILM 740 art 14(1).

${ }_{75}^{74}$ See for an overview E Bjorge, The Evolutionary Interpretation of Treaties (Oxford University Press 2014).

${ }^{75}$ Sands and Peel (n 9) 244.

${ }^{76}$ Rio Declaration on Environment and Development in 'Report of the United Nations Conference on Environment and Development' UN Doc A/CONF.151/26 (vol I) (12 August 1992) Principle 7.

${ }^{77}$ UNFCCC (n 26) art 3(1) (emphasis added).

${ }^{78}$ Paris Agreement (n 73) art 2(2).

${ }^{79}$ See C Voigt and F Ferreira, 'Differentiation in the Paris Agreement' (2016) 6 Climate Law 58.
} 
the principle broke loose from the historical, bifurcated understanding that it establishes differentiation between developed and developing countries to a new understanding which takes account of the multipolar global order, marked by constant political, economic and social power changes. A codification of the principle in a general treaty bears the danger that it might be generalized (again) to the original expression, thereby losing the progress made in the context of the UN climate change regime. ${ }^{80}$

A codification of principles would necessarily lead to more generalization, in which nuances and specific expressions could be hard to maintain. This is due to the nature of multilateral negotiations, which mainly involve political compromises and decision making by consensus, and more often than not result in low or lowest common denominator outcomes. This could lead to a regression towards minimum standards, which - once codified - could present an obstacle to further specification and increased ambition. It would therefore be important to ensure that any attempts at codification complement, and not replace, the progressive specification of principles achieved in sector-specific MEAs. Moreover, the level of specificity differs from treaty to treaty for several reasons, for instance related to the nature of the environmental challenge at stake, the progress made in legal development, or the specific political compromises involved. These differences need to be carefully assessed and may not easily allow for a general application of certain principles.

No new treaty development should contradict or lead to backsliding or regression from achieved specificity and concreteness. Any codification should be without prejudice to the legal developments already achieved, recognize issue-specific contexts and should progress from there. Legal means to do this could involve, for example, the use of 'non-prejudice' or 'nonregression' or 'progression' clauses, or the explicit recognition of the priority of lex specialis in sector-specific MEAs. A 'classification' of principles as lex specialis might, however, not be easily achieved. Neither might it lead to clear answers. Some States may be more than ready and willing to accept that a later and more general expression of a principle prevails over earlier, more specific, expressions of that principles, based the concept of lex posterior. At best, this situation could lead to confusion; at worst it could undermine earlier, but more specific expressions.

Second, as mentioned above, principles are genuinely indeterminate and thereby a dynamic element of international law. Codifying principles could inhibit such dynamism by 'freezing' them. While their expression would most likely still be abstract and general, it might become more difficult to adjust them to new circumstances, questions, situations and challenges. This raises the need for regular review, and this, in turn, the issue of continuous, repeated and time-consuming negotiations.

Third, as sectoral MEAs continue to grow and develop, their principles do the same. Attempts to codify principles would need to take account of and be informed by these ongoing processes, while avoiding to create overlaps and duplication of efforts. Careful coordination would be key here, but might in practice be difficult to achieve. Different processes have their own dynamics, epistemic communities, experts and party delegations. It might be a difficult task for those working on a codification of principles to be aware of and well informed by all other parallel processes which might also involve further work on principles.

Fourth, codification of principles might 'import' context-specific concerns and the sensitive compromises made in one area of international environmental law to other areas,

\footnotetext{
${ }^{80}$ This would be even more worrisome as a general application of this principle is not evident. The International Tribunal for the Law of the Sea (ITLOS) Seabed Dispute Chamber made clear in its Advisory Opinion on Responsibilities and Obligations in the Area that the obligations in question applied equally to all sponsoring States, whether developed or not, and required equality of treatment; see Responsibilities and Obligations of States Sponsoring Persons and Entities with Respect to Activities in the Area (Advisory Opinion) [2011] ITLOS Rep 10 paras $153-161$.
} 
where the same concerns may be less relevant. To give an example, a general codification of the principle of 'common but differentiated responsibilities and respective capabilities' might re-introduce the notion of bifurcation between developed and developing countries and different legal obligations or a different standard of care in relation to capacities to areas of international law, where such differentiation is not only less prominent (for example in the context of conservation of biological diversity), but where introducing differentiation might even undermine the robustness of the regime (for example in human rights regimes where differentiation and different obligations relative to 'responsibilities and capacities' is - and needs to be - absent).

In sum, any attempt to codify legal principles needs to take account of the necessity of dynamism, abstractness, indeterminacy and generality inherent in principles. These features are necessary for principles to be relevant and useful in the guidance of the ever-changing and growing body of international law. One has to be mindful that codification holds the danger of 'casting principles into stone', backtracking from and/or inhibiting their further evolution. At least two things need to be avoided: (i) over-simplification and generalization where specificity has already been achieved; and (ii) the reduction to minimum standards, which could prevent the future specification and evolution of principles.

\subsection{Other means to fill gaps and/or to add value}

While the codification of principles might add some value, there are also other ways to enhance the effectiveness of international environmental law. A Global Pact for the Environment does not need to be limited to one aspect (i.e. principles), one strategy (i.e. codification) or one instrument (i.e. treaty). Rather, a Global Pact could capture several aspects and provide a 'toolbox' for the general improvement of international environmental law and the enhanced effectiveness of environmental protection. As identified by the UNSG report and repeatedly mentioned during the OEWG sessions, a Global Pact could add value by promoting and facilitating at least five non-mutually exclusive developments.

First, it could aim at supporting better coordination and synergies between MEAs. Under the premise that the unsystematic nature of international law poses the risk of proliferation of norms and institutional as well as normative competition and inconsistencies (sometimes characterized as 'treaty congestion'), ${ }^{81}$ increased coordination between different treaty regimes and normative developments might be necessary to avoid ineffective legal responses or inefficient allocation of resources. This applies not only within the field of international environmental law, but also - and perhaps even more so - between MEAs and other instruments that directly or indirectly affect the environment, such as trade law, investment law, intellectual property law, etc. Many MEAs deal with a large diversity of issues that require collective action and international cooperation. This assumes issue-specific treatment within and coordination and cooperation among international regimes.

In this context, the Global Pact for the Environment could function as a 'compact' for bringing together the different tools and approaches to enhance coordination. The answer to coordination challenges is not always 'making more law', but first and foremost 'making existing instruments work'. Coordination between treaties can be achieved by various means. These include both procedural and substantive measures.

Procedurally, there exist various options, including: (i) creating clusters and synergies between conventions (e.g. as has been done for the Rotterdam, Basel and Stockholm Conventions ${ }^{82}$ ) through back-to-back or joint meetings, joint budgeting, sharing of secretariats or collaboration of secretariats; (ii) mapping of existing global and regional action plans and

\footnotetext{
${ }^{81}$ Weiss (n 14).

${ }^{82} \mathrm{See}<\mathrm{http}: / /$ www.brsmeas.org/Decisionmaking/Overview/AboutSynergies>.
} 
agreements to create an overview of coverage and identify interlinkages; (iii) avoiding duplication of reporting and/or monitoring processes by developing common reporting channels without creating additional burdens ("integrated reporting"); (iv) developing implementation guidelines for MEAs; (v) further development of mutual supportiveness, or (vi) the establishment of joint clearing houses to share experiences, lessons learned and best practices across MEAs.

So far, despite some isolated attempts of collaboration between secretariats and creating synergies at the international level, the coordination of partial and sectoral measures in international law is still in its infancy - and existing attempts have not led to significantly increased environmental efficiency. Coordination therefore remains mainly an issue of domestic implementation of international law and, as such, often a challenge.

Cooperation and coordination can also be achieved by advancing or managing treaty substance: where gaps can be identified, they could be addressed by possible amendments or additional guidance through decisions by the governing body, rather than by negotiating new conventions (e.g. the Kigali Amendment to the Montreal Protocol on hydrofluorocarbons ${ }^{83}$ ). Also, 'coordinating' guidance can be developed for existing treaties, including on the guiding principles and concepts already contained in international instruments, such as the Sustainable Development Goals. This way, coordination can be achieved in a more expeditious fashion, rather than through the time-consuming development of a new legal instrument.

Second, a Pact could also take the shape of a framework or umbrella document, aiming at fitting together the different sectoral and geographical agreements under a common vision of international environmental law for the Anthropocene. ${ }^{84}$ In this context, it could identify, map and classify global environmental challenges and their necessary responses in an integrated, interdependent and holistic manner. This could be done in a high-level instrument, for example a resolution by the UN General Assembly or the UN Environment Assembly.

Third, a Global Pact could address implementation deficiencies. Effective implementation of existing MEAs has been identified as a key challenge. ${ }^{85}$ Implementation deficits arise for different reasons, ranging, for example, from capacity challenges, the need for facilitation and compliance, insufficient monitoring and law enforcement, to lack of political will. Coherence and coordination at the international level have been identified as easing implementation challenges, but are seldom seen as the only ways to achieve effective implementation. ${ }^{86}$ A Pact could aim at bringing together state and non-state actors in a global compact to raise the necessary means for the effective implementation of environmental agreements. This could lead to cooperation on increased capacity-building across State borders and across the public/private divide. It could bring private companies and corporations onto the scene and provide a space for interaction on addressing financial and technology gaps.

Fourth, a Pact could act as a 'mediator' between international environmental law and other areas of international law, by investigating in and reconceptualizing the relationship between environmental protection and other objectives. As stated above, the strength of MEAs and their effective implementation can be supported or inhibited by other fields of international law. A Pact could assess and address, on a principled basis, how different objectives expressed in international treaties should apply and be weighted against each other, especially in cases of normative conflict.

Fifth, the initiative for a Global Pact for the Environment could be of a more 'forwardlooking' nature. It could aim at charting and increasing awareness of future environmental

\footnotetext{
83 'Further Amendment of the Montreal Protocol: Submitted by the Contact group on HFCs' UN Doc UNEP/OzL.Pro.28/CRP/10 (14 October 2016).

${ }^{84}$ See Kotzé and French (n 29).

${ }^{85}$ UNEP (n 17).

${ }^{86}$ ibid.
} 
challenges or technologies which are not yet covered by international treaty law, such as negative emissions technologies and solar radiation management, microplastics in the oceans, nanotechnology or quantum computing. It could help set in motion international discourses under the UN or other places that seek to assess the risks and benefits associated with these challenges and technologies, and the appropriate legal framework to address them.

\section{CONCLUSIONS}

This article has shown that there are several shortcomings and deficiencies in international environmental law. Some are inherent in the general nature of international law, while others are intentional and negotiated 'by design'. Still, some aspects of international environmental law deserve improvement. This applies, in particular, to increasing the effectiveness of implementation of and compliance with existing agreements, as well as enhancing coordination and synergies among MEAs as well as between MEAs and other international agreements, with a view to improving environmental protection.

A Global Pact for Environment could be the right thing at the right time to bring such improvements about. Its architects, however, should be guided by considerations of function and functionality above form. In this regard, it is important to clearly carve out where and how such an initiative could add value to the existing body of international environmental law.

This could well be done by consolidating, clarifying and codifying the content and status of (some) environmental principles. Such consolidation, if feasible, might prove helpful in directing the further development of international (and national) environmental law, or in the relationship between environmental and not-so environmental international law, or in the guidance to jurists and courts at the international and the national level.

However, there are significant risks involved in such an exercise. In addition to the risk of difficult and time-consuming negotiations, they include, inter alia, (i) regression from achieved levels of specification of principles in issue-specific context of MEAs, (ii) inhibition of the future, dynamic development of these principles, (iii) duplication of efforts and inconsistencies, (iv) importing of issue-specific sensitivities and compromises into the general body of international environmental law or to other areas of international law. Accordingly, drafters would need to act with extreme care and great caution.

Different means to increase the effectiveness of international environmental law exist, among which the development of new treaty law is only one; and one that should be carefully assessed. New treaty law needs to be manageable and efficient, and fit within the pre-existing structure of international environmental treaties. The risk is that further expansion could lead to 'over-commitment' and capacity challenges, which could exacerbate the implementation challenges and eventually further undermine the effectiveness of international environmental law.

Three such challenges have been noted with regard to treaty developments. First, the basic ability of States to implement and comply with substantive obligations could become undermined by an unmanageable number of commitments. Second, as treaty bodies and institutions proliferate along with the growing corpus of treaties, the capacity of States to meaningfully participate in these institutions might erode, followed by institutional competition and a growing need to coordinate supervisory responsibilities and administrative requirements. Third, the ability of States to adequately monitor and report on the implementation of their obligations, as international environmental treaties increasingly require, could be impeded unless monitoring and reporting can be done in an integrated manner. ${ }^{87}$

\footnotetext{
${ }^{87}$ D Anton, “"Treaty Congestion" in International Environmental Law' in S Alam et al (eds), Routledge Handbook of International Environmental Law (Routledge 2013) 651.
} 
As a general matter of legal effectiveness, in the face of the apparent continuing environmental decline and despite the normative build-up, what is needed might be less the adoption of new instruments than better coordination of, and more effective implementation of and compliance with, existing ones. ${ }^{88}$

Yet, a Global Pact for the Environment could be and do many things. It does not need to be limited to a new treaty which codifies environmental principles. It could - and should be guided by the question of 'what is needed' to increase the effectiveness of environmental protection. In this sense, a Pact could address implementation challenges, coordination deficits between MEAs (and between MEAs and other international treaties) or bring together actors from the public and private sector in the global concern for environmental protection. It could provide a common vision for global environmental action and/or a framework for bringing the different pieces, i.e. sectoral and spatial agreements, together. Moreover, it could advance the development of international environmental law into fields and areas so far uncovered. In sum, the initiative and the current political momentum around it present an opportunity not to be missed.

Christina Voigt is professor of law at the University of Oslo, Department of Public and International Law. She was one of the three legal experts who supported the drafting of the report of the UN Secretary-General on 'Gaps in International Environmental Law and Environment-Related Instruments: Towards a Global Pact for the Environment' UN Doc A/73/419 (November 2018).

The views expressed in this article are strictly personal and the sole responsibility of the author.

\footnotetext{
${ }^{88}$ M Koskenniemi, 'Breach of Treaty or Non-Compliance? Reflections on the Enforcement of the Montreal Protocol' (1992) 3 Yearbook of International Environmental Law 123.
} 